\section{ECONOMICS}

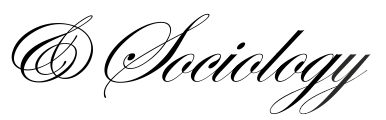

Kowalczyk-Rólczyńska, P. (2020). Valuations of benefits paid from equity release products in the context of the changing financial requirements of elderly persons. Economics and Sociology, 13(1), 74-89. doi:10.14254/2071-789X.2020/13-1/5

\title{
VALUATIONS OF BENEFITS PAID FROM EQUITY RELEASE PRODUCTS IN THE CONTEXT OF THE CHANGING FINANCIAL REQUIREMENTS OF ELDERLY PERSONS
}

\author{
Patrycja Kowalczyk- \\ Rólczyńska \\ Wrockaw University of Economics \\ and Business, \\ Wroctaw, Poland \\ E-mail: \\ patrycja.kowalczylk@ue.wroc.pl \\ ORCID 0000-0002-7952-7678
}

Received: August, 2019

1st Revision: November, 2019

Accepted: February, 2020

DOI: $10.14254 / 2071-$

789X.2020/13-1/5

JEL Classification: J26, J14, G21, G22

\begin{abstract}
This paper presents a comparison of valuations of benefits paid under the framework of equity release products. Such benefits are adjusted to the changing structure of financial needs and requirements brought about by ageing processes and health deterioration among the elderly. The first of the two adopted variants takes into consideration the number of years for which elderly persons may reasonably expect to retain good health. The second variant is grounded on the assumption that the demand for financial support will increase at each consecutive stage of the ageing process. Valuations of benefits paid for each scenario were calculated using life annuities. The findings suggest that the values of benefits paid in each of the scenarios are higher for males. However, compared to old-age pension benefit values, both seem to offer a more profitable solution for females.
\end{abstract}

Keywords: elderly persons, equity release, benefits, life annuities

\section{Introduction}

Recent years have brought and intensified a wealth of changes in the demographic structure of most European countries. Life expectancy ratios have been increasing from the early 1960s, a trend officially described as one of the most spectacular advancements in the history of humankind (Bloom et al., 2015). Moreover, it is generally assumed that this trend will continue in the foreseeable future. According to European Commission estimates (2018), from 2016-2070 the life expectancy at birth of an average EU Member State citizen will rise by 7.8 years for males and 6.6 years for females. In addition, this trend appears to be coinciding with a significant decrease in the number of births, which translates into an increase in the proportion of older people in society. It should also be noted that in some countries (particularly those in early stages of economic development), problems related to societal ageing are amplified by steep negative net migration rates - primarily manifested in younger people migrating to more developed regions for economic reasons. This, in turn, presents a serious challenge for existing pension systems, which have already been subject to reforms in almost 
all EU Member States (Lannoo et al., 2014; Whiteford \& Whitehouse, 2006). Consequently, numerous economies have adopted a multi-pillar structure for their pension systems (Eichhorst et al., 2011), based on the accumulation of capital, to warrant proper provision of pension benefits. However, ongoing changes in the general age structure, including a steady decline in the workers-to-pensioners ratio, will impeded the amelioration of the demographic risk in the foreseeable future (Kowalczyk-Rólczyńska, 2016; Melis \& Trudda, 2010), particularly the longevity risk (Barrieu et al., 2012; Fong, Mitchell \& Koh, 2011; International Monetary Fund, 2012; Bisetti \& Favero, 2014). These effects will generate an additional load in the form of increased payments from the obligatory part of the pension system, posing a potential challenge to the long-term stability of the system and the volume of pension benefits paid in the future. It is therefore highly advisable for individuals to participate in supplementary forms of pension system throughout their working lives, with a view to negating at least some of the expected decline in income post retirement. One of the main barriers to the development of individual pension savings is the inadequate level of financial education in modern societies, a trend widely presented in the literature and discussed by Clark et al. (2003), Lusardi (2009), OECD (2008), Ntalianis and Wise (2011), and Chou et al. (2014).

To maintain a supplementary source of income past the age of retirement, people entering the senior years of their lives with a scarce supply of capital to support their pension (or those who, for various reasons, have no savings assigned for this purpose) may elect choose one of the available equity release products.

The main purpose of this paper is to compare the value of benefits paid from equity release products taking into account the changes in the financial needs of elderly customers brought about by advancing age and deteriorating health. To achieve this, different life annuity formulas were assessed. Valuations were conducted for the Polish market, which offers good potential for the development of equity release products, as attested by the Towers Watson report (2013) and emphasised by conditions such as the aforementioned shift in longevity projections, the steady decrease in the net pension replacement rate, and the high share of residential property ownership and low share of savings among elderly households. As attested by OECD reports $(2011,2017)$ on the Polish market, the net pension replacement rate in 2010 was valued at $50.6 \%$ for women and $68.2 \%$ for men. In subsequent years, the rate began a steady decline, falling to the 2016 values of $38.6 \%$ for men and $34.1 \%$ for women. Furthermore, most elderly households hold the ownership rights to their homes. As attested by the 2016 report of the Central Statistical Office, $76.4 \%$ of Polish elderly households have retained ownership rights to residential properties (CSO, 2017). By contrast, the levels of savings accumulated by elderly households in Poland are less than adequate. According to reports from the National Bank of Poland (NBP, 2017), in the year 2016 the average value of financial assets held by households managed by persons aged 65 or over was equivalent to approximately six times the value of an average monthly salary in the private sector.

The main contribution of this paper lies in the application of life annuity valuation formulas to estimate benefits from equity release products, which tend to increase in line with the growing needs of elderly persons. The postulated approach and the results obtained may be of use both to the scientific community and to financial institutions or economic entities offering equity release products on the market. Estimating the value of benefits by taking into account increasing financial needs has not previously been proposed in the literature.

The content of the paper is organised as follows: subsequent to the introductory comments presented in this section, chapter 1 examines the wealth of literature on the most important aspects of equity release, including the estimation of payment values from equity release products. Section 2 presents two methods used for the valuation of benefits. Section 3 provides an overview of the results obtained from the valuations and compares these to old-age 
pension benefits received from the obligatory part of the pension system. The final segment of this paper presents the main conclusions drawn from this research.

\section{Literature review}

Equity release products are targeted at residential property owners and are designed to convert a previously illiquid asset into cash payments (Alai et al., 2013). Furthermore, as noted by Reed and Gibler (2003) and Li, Hardy, and Tan (2010), products of this type are typically reserved for customers classified as asset (house) rich and cash poor, which comprises those with a low income who hold ownership rights to residential properties of medium-to-high value. Benefits paid as part of the equity release product may offer a profitable solution for the lone elderly faced with relatively steep costs of sustenance or for those who (for a variety of reasons) face financial problems due to scarce or non-existent support from their families. This type of product may also be an attractive solution for those customers who, approaching retirement age, wish to safeguard against potential risks and expenses, be these foreseeable, such as home maintenance and modernisation, financing of private health care or long-term nursing assistance, and a regular supply of expensive medication (Terry and Gibson, 2006), or unanticipated. It should also be noted that - for many people approaching retirement age - the release of equity accumulated in property may be the only form of funding available to enable them to pursue their dreams and aspirations past the period of gainful employment.

The financial needs and requirements of elderly households are naturally influenced by age, health conditions, and the self-reliance of their members. These, in turn, are closely related to phases of old-age. The World Health Organisation (WHO, 2004) classified old age into three stages: the "young old" (60-74 years of age), the "old-old" (75-84), and the "oldest old" (past the age of 85). Similarly, Zizza, Ellison and Wernette (2009) employed the following classification: young-old (65-74 years of age), middle-old (75-84), and oldest-old (85 and more). Taking into account the previously discussed shift in longevity trends, such classifications may reasonably be expected to shift in the same direction. In particular, the formal threshold defined for the final phase may soon move past the present mark of 85 years of age, mostly due to a steady increase in the Healthy Life Years average calculated for persons reaching the age of 65. According to European Commission reports, the average Healthy Life Years index for EU residents aged 65 in 2010 was 8.7 years for men and 8.8 years for women. Following a systematic year-by-year increase, the HLY index reached values of 9.8 for men and 10.1 for women by 2016. Therefore, notwithstanding such factors as household income level, the value of residential properties, and the 'health' of family relations of the elderly, the age and health condition of senior citizens remain the most important determinants of their willingness to use some form of equity release product, as their decisions are strongly affected by the perceived adequacy of the benefits obtained from such a release.

In general, equity release products are construed on the basis of two fundamental models: the sale model (otherwise known as home reversion) and the loan model (also referred to as reverse mortgage or lifetime mortgage). In a detailed evaluation of Equity Release Schemes (ERS), Reifner et al. (2009) highlighted the most important criteria used to distinguish the two models. These include the following:

(1) In the loan model, products are offered by banks or other crediting institutions in the form of an obligation to provide the borrower (customer) with regular payments (or a lump sum) in exchange for the transfer of their rights to a residential property after their death. Property maintenance costs in this model are covered by the borrower; and the sum of received payments may be returned to the lender by the borrower or his/her inheritors.

(2) Under the sale model, an insurance company or other institution takes up the obligation to provide the customer with regular payments in exchange for the right of ownership to the 
residential property (or parts thereof), effective from the moment the agreement is signed. In this model, the seller retains their right of lifetime lease for the property. Under this scheme, home maintenance costs are borne by the product provider and the sums paid to the customer cannot be returned.

The equity release market is a well-established phenomenon in the history of finance. As noted by Guerin (2012), the earliest application of the reverse mortgage on the US market can be traced back to the year 1961. In an analysis of the early stages in the development of the US reverse mortgage market, Mazonas (2011) emphasise the fact that, in the 30 years following the introduction of the loan model of equity release, reverse mortgages have experienced limited acceptance among consumers. Regarding earlier attempts to introduce the equity release solution on European soil, the Aviva and Norwich Union report (2008) clearly state that the first product of this type was introduced to the UK market in 1965 and was known as an reversion income scheme. In time, the experience gathered on US and UK markets served to reinforce and mature equity release solutions and schemes and extend them to other areas of Europe and also to Asia (Heo, An and Hong, 2016; Kobayashi, Konishi and Takeishi, 2017) and Australia.

Practical aspects in the operation of specific equity release schemes have been widely discussed in the literature. One of the most important issues in this regard has been the selection of various forms of payments generated on the basis of the two available models. As pointed out by Nakajima and Telyukova (2013), Bhuyan (2011), and Johnson and Simkins (2014), customers on the US market can choose from as many as 5 distinct types of benefits paid under the reverse mortgage. The first such option is a tenure - involving monthly payments of equal value paid for the duration of the borrower's lifetime (or that of the last survivor, if applicable); borrowers retain their right to live in the residential property. The second option: a term involves monthly payments of equal value paid for a specific duration. Thirdly, a line of credit - is an option providing irregular payments in response to the borrower's financial needs within the limits set in the contract. A fourth option, a modified tenure - is a combination of a credit line and monthly payments, released for as long as the borrower lives in the home as a primary residence. The final option is the modified term - a combination of a credit line (indefinite) and equal monthly payments for a predetermined period. Alai et al. (2014) provide a similar overview of equity release forms available on the Australian market. Under the loan model of equity release, and depending on the form of contract, borrowers may choose between the following payment plans: a lump sum, income stream, a line of credit, or a combination of these. For home reversion, the only option available is the lump sum. The UK market, in accordance with the Equity Release Council (2016), provides lifetime mortgage products with payments set as a single lump sum and/or a lump sum paid in smaller amounts up to the maximum limit agreed with the plan provider. The home reversion model, by contrast, offers benefits paid either in a lump sum or in regular payments. Compared to these, the Polish market is much less developed. For instance, for benefits paid to elderly customers based on sale model agreements held with a mortgage fund, the only available option is regular monthly lifetime allowances. Conversely, agreements based on the loan model of equity release consist of a onetime lump sum payment or a series of regular payments for a specified term. Although the loan model has been formally regulated in the Polish legislature for five years, this class of products has not yet been offered by any of the commercial banks in Poland (Kowalczyk-Rólczyńska, 2015). However, there are plans for a formal revision of pending legislative regulations with a view to opening the market for equity release products to other institutions, such as insurance companies or financial entities with sufficient guarantee capital.

The practical organisation of equity release products is burdened with various types of risks to the detriment of both the plan provider and the product recipient. Of these, the interest rate risk, housing price risk, and longevity risk have been analysed in detail by, among others, Chen 
and Wu (2014), and Alai et al. (2014). Tunaru (2017) has since expanded the list to include morbidity risk, legal risk, transfer risk, adverse selection risk, and repayment risk. The securitisation of selected forms of risk associated with the reverse mortgage has been addressed in detail by Wang, Valdez and Piggott (2008), Huang, Wang and Miao (2011), and Yang (2011). Research by Davidoff and Welke (2004) focused on the risk of adverse selection and moral hazard in relation to the reverse mortgage market. It is important to note that the specificity of individual markets and the available products that offer conversion of the capital accumulated in property may bear other types of risk. These may emerge in association with various determinants and legislative, socio-economic, or cultural conditions. For example, because the Polish market is a domain ruled exclusively by the sale model and offered by institutions outside the formal supervision of the Polish Financial Supervision Authority, the structure of risk is strongly affected by the risk of default and the risk of provider insolvency. Numerous other factors affecting the demand for equity release products should also be emphasised; an overview of these, together with an analytical evaluation of the appeal of reverse mortgage solutions in various segments of elderly households can be found in, for example, Nakajima and Telyukova (2017).

Decisions to choose an equity release product are strongly influenced by the level of benefits offered by specific products. Various approaches to the valuation of payments are presented in the professional literature, with a major focus on products construed on the basis of the loan model. The value of benefits is influenced by several factors, all of which should be taken into account during calculations. Fornero, Rossi and Brancati (2016) based their research on a formula for the estimation of yearly benefits paid to the borrower under the tenure plan, with proper representation of such factors as the housing equity, the net average housing price appreciation, the approximated interest rate, life expectancy (calculated as 100 minus current age), and all initial costs and fees. Alai et al. (2014) compared cash flows and risk profiles from the provider's perspective for reverse mortgage and home reversion contracts. Their calculations were based on the following: the termination model, the vector autoregressive model, and stochastic discount factors. For the estimation of risk, the authors employed Valueat-Risk (VaR) and Conditional Value-at-Risk (CVaR). Gupta (2016) proposed an intriguing approach to the estimation of monthly, quarterly, and annual payments under reverse mortgage contract based on financial mathematics principles. Marciniuk (2014) construed her valuations of payments from both the sale and the loan model using life and other certain annuities. Wang and Kim (2014) related their valuations of payments under reverse mortgage contracts to the following: present value of the net borrowing limit of the reverse mortgage (related to: house price, loan to value, initial guarantee fees), remaining life expectancy, and pension interest rates. For the valuation of reverse mortgages with tenure payments, Lee, Wang and Huang (2012) proposed a specific analytic valuation framework with mortality risk, interest rate risk, and housing price risk. This determines fair premiums when the present value of such premiums equals the present value of contingent losses. Additionally, Choi (2019), focusing on the Korean market, estimated the monthly payment from the actuarial pricing model of the reverse mortgage, which reflects house price growth, while Lee, Kung and Liu (2018) explored both the lump-sum and annuity payment plans using stochastic dominance to compare reverse mortgage products from the supplier's point of view.

In sum, this brief overview of the literature suggests that the wealth of available research offers a multi-aspectual approach to the valuation of equity release products. However, current progress and trends in the ageing population will soon compel the market to update and revise their offer of financial products and services so that they are adjusted to the needs and requirements of the growing population of elderly persons. This will naturally include changes to existing equity release products. Therefore, although it has not yet been proposed, an 
approach based on payments increased in response to the changing needs of the elderly appears to be the most attractive prospect.

\section{Methods for the valuation of benefits paid from equity release}

As noted in earlier sections, the central objective of this paper will be achieved through the use of different life annuity formulas. The valuation of annuities was adjusted to the changing needs of elderly households and conducted in two variants ${ }^{1}$. The first variant examines the number of years for which the elderly person maintains conditions of good health. The second variant is based on the assumption that the needs of elderly persons will grow with the passing of each consecutive stage of the ageing process. Both variants operate on the common assumption that the elderly person enters the equity release contract in the first (initial) stage of the senior age classification.

Because the calculations presented in section 3 are designed for the Polish market, the postulated formulas address two forms of payment: temporary benefits and life annuity benefits. Lifetime products on the Polish market are offered under the sale model and paid from mortgage funds, whereas term agreements are legally obliged to follow the principles defined for the loan model of equity release. For valuations related to reverse mortgage products, it is important to emphasise recent legislative changes imposing an obligation on banks and credit institutions to cooperate with a registered actuary.

\subsection{Valuation of benefits paid under a two-phase plan of payments}

This variant presents three formulas for the valuation of payments offered as part of equity release products; the first two cases represent term benefits, the third represents a lifetime benefit.

In the first case, benefits are paid at the beginning of every month over as a set term of $k$ years and at $R$ value, followed by a period of $l$ years at a value of $\tilde{R}$. For this purpose, the actuarial present value of benefits paid (in advance) by the provider of equity release products to a person aged $x$ at the beginning of each $m$-th month over a period of $n$ years and valued as: $R$ for the period of $k$ years, and $\tilde{R}$ for the period of the next $l$ years $(n=k+l)$, as long as the person aged $x$ remains alive, can be presented as:

$$
K_{0}=12 \cdot R \cdot \ddot{a}_{x: \bar{k} \mid}^{(m)}+12 \cdot \tilde{R} \cdot{ }_{k \mid} \ddot{a}_{x: \bar{l} \mid}^{(m)}
$$

where: $R$ - the value of each monthly annuity payment due for the first $k$ years, $\tilde{R}$ - the value of each monthly annuity payment due for the next $l$ years, with $\tilde{R}=R(1+r), r$-valorisation rate, $R W_{0} \cdot \alpha=K_{0}$ - the value of equity release at the moment an agreement is signed between an elderly person and the provider of equity release products $\left(R W_{0}-\right.$ the market value of the residential property, $\alpha$ - percentage of equity release (Loan to Value)), $\ddot{a}_{x: k \mid}^{(m)}-$ the actuarial present value of $k$-year temporary life annuity of 1 per year, payable in instalments in the amount $1 / \mathrm{m} \mathrm{m}$-times a year at the beginning of every $1 / \mathrm{m}$ part of a year over $k$ years as long as a person aged $x$ remains alive. It is defined using the following formula (Bowers, 1997):

$$
\ddot{a}_{x: k \mid}^{(m)}=\frac{1}{m} \sum_{j=0}^{k \cdot m-1} \frac{j}{v^{m}} \cdot \frac{{ }_{j}}{m} p_{x}
$$

\footnotetext{
${ }^{1}$ All formulas presented in this section were derived by the author of this paper
} 
where: $v^{\frac{j}{m}} \cdot{ }_{\frac{j}{m}} p_{x}-$ the actuarial present value of a payment valued at 1 at the moment of $\frac{j}{m}$, $v^{\frac{j}{m}}$ - the discount factor, $\frac{j}{m} p_{x}$ - probability for a person aged $x$ to live for the next $\frac{j}{m}$ periods of time.

Following preliminary simplifications and assuming a uniform distribution of deaths over the course of each year, equation (2) can be presented as follows (Gerber, 1990):

$$
\begin{array}{r}
\ddot{a}_{x: \overline{k \mid}}^{(m)}=\alpha(m) \cdot \ddot{a}_{x: \overline{k \mid}}-\beta(m) \cdot\left(1-{ }_{k} p_{x} \cdot v^{k}\right) \\
\alpha(m) \approx 1, \quad \beta(m) \approx \frac{m-1}{2 m}
\end{array}
$$

${ }_{k \mid} \ddot{a}_{x: \bar{l} \mid}^{(m)}$ - the actuarial present value of $k$-year deferred $l$-year temporary life annuity of 1 per year, payable in instalments in the amount $1 / \mathrm{m} m$-times a year at the beginning of every $1 / \mathrm{m}$ part of a year over $l$ years as long as a person aged $x$ remains alive, is calculated as follows:

$$
{ }_{k \mid} \ddot{a}_{x: \bar{l} \mid}^{(m)}=\frac{1}{m} \sum_{j=k \cdot m}^{l \cdot m-1} v^{\frac{j}{m}} \cdot{ }_{\frac{j}{m}} p_{x}
$$

In the second case, benefits are paid in the form of annuities at the beginning of each year for $n$ years in two phases: for the first $k$ years the value of annuities is valorised by the current inflation rate, and for the remaining $l$ years by the annual average growth rate calculated for medical expenses among the elderly segment of the population. For the current purpose, an approach based on geometrically increasing annuity can be employed. In this model, the value of the first benefit paid under the geometrically increasing annuity (at the beginning of the first year) for a person aged $x$, assuming that - for the next $k$ years - the value of annuities will increase by the current inflation rate, followed by the next $l$ years (with: $n=k+l$ ) of valorisations based on the annual average growth rate calculated for medical expenses in the elderly segment of the population will amount to:

$$
K_{0}=R \cdot \ddot{a}_{x: \bar{n} \mid i_{1}}
$$

where, in line with Dickson, Hardy and Waters (2013):

$$
\begin{gathered}
\ddot{a}_{x: \bar{n} \mid i_{1}}=\sum_{t=0}^{n-1}(1+j)^{t} \cdot v^{t} \cdot{ }_{t} p_{x} \\
i_{1}=\frac{1+i}{1+j}-1=\frac{i-j}{1+j}
\end{gathered}
$$

$v=1 /(1+i)$ - discount factor, $j$ - indexation rate.

In the third case, benefits are paid at the beginning of each month for the duration of the beneficiary's lifetime, in the amount of $R$ for the first $k$ years and $\mathrm{f} \tilde{R}$ for the remaining period. For this purpose, the actuarial present value of benefits paid (in advance) to a person aged $x$ at the beginning of each $m$-th period in the amount of $R$ for the first $k$ years, and $\tilde{R}$ for the remaining duration of the contract (as long as a person aged $x$ remains alive), can be expressed as:

$$
K_{0}=12 \cdot R \cdot \ddot{a}_{x: \bar{k} \mid}^{(m)}+12 \cdot \tilde{R} \cdot{ }_{k \mid} \ddot{a}_{x}^{(m)}
$$

where: ${ }_{k \mid} \ddot{a}_{x}^{(m)}$ - the actuarial present value of $k$-year deferred whole life annuity of 1 per year, payable in instalments in the amount $1 / \mathrm{m} \mathrm{m}$-times a year at the beginning of every $1 / \mathrm{m}$ part of a year as long as a person aged $x$ remains alive, which, in line with Bowers (1997), may be presented as:

$$
{ }_{k \mid} \ddot{a}_{x}^{(m)}=\alpha(m) \cdot{ }_{k \mid} \ddot{a}_{x}-\beta(m) \cdot{ }_{k} E_{x}
$$

${ }_{k} E_{x}=v^{k} \cdot{ }_{k} p_{x}-$ the actuarial discount factor. 


\subsection{Valuation of benefits paid under a three-phase plan of payments}

This variant presents two formulas for the valuation of payoffs generated by equity release products. The first formula applies to benefits paid for a set term (under the loan model); the second formula applies to benefits paid for the beneficiary's lifetime (under the sale model).

We first examine the case where benefits are paid for $n$ years at the beginning of each month and increase in value with the passing of each phase of ageing in the beneficiary aged $x$. For this purpose, the actuarial present value of benefits paid (in advance) by the provider of equity release to a person aged $x$ at the beginning of each $m$-th month over a period of $n$ years as long as the person aged $x$ remains alive and valued as: $R$ for the period of $k$ years, $L$ for the next $l$ years, and $P$ for the next $p$ years (with $n=k+l+p$ ), can be expressed as follows:

$$
K_{0}=12 \cdot R \cdot \ddot{a}_{x: k \mid}^{(m)}+12 \cdot L \cdot{ }_{k \mid} \ddot{a}_{x: \bar{l} \mid}^{(m)}+12 \cdot P \cdot{ }_{k+l} \ddot{a}_{x: \bar{p} \mid}^{(m)}
$$

where: $L=R(1+r), P=R(1+r)(1+g)$, and $r, g$ - benefit increase rates.

We then examine the second case where benefits are paid at the beginning of each month for the duration of the beneficiary's lifetime and are incremented in value with the passing of each consecutive phase of the ageing process (for a person $x$ years of age). Taking account of the fact that the actuarial present value of benefits paid (in advance) to a person aged $x$ by a mortgage fund at the beginning of each month and in values of: $R$ for $\mathrm{k}$ years, $L$ for the next $l$ years, and $P$ for the remaining years (as long as person aged $\mathrm{x}$ alive), this is expressed as:

$$
K_{0}=12 \cdot R \cdot \ddot{a}_{x: \bar{k} \mid}^{(m)}+12 \cdot L \cdot{ }_{k \mid} \ddot{a}_{x: \bar{l} \mid}^{(m)}+12 \cdot P \cdot{ }_{k+l} \ddot{a}_{x}^{(m)}
$$

\section{Results and discussion}

Benefits paid on the Polish market under the framework of the sale model of equity release are predominantly valued in relation to the value of the residential property and the beneficiary's age and gender. However, it may be difficult to ascertain the composition of factors that influence future values of the benefits paid under plans construed in accordance with the loan model of equity release.

To achieve the main objective of this research, values of benefits were calculated for the payment variants defined in section 3 . Thus, they were valued separately for women and men aged 65, and for owners of property located in Warsaw (the capital of Poland) or in Wroclaw ${ }^{2}$ (the fourth largest city in Poland). The focus on large cities stems from the observation that mortgage funds operating on the Polish market offer their sale model of equity release primarily to those elderly persons who own a valuable residential property in one of the large agglomerations. The valuation formulas were based on 2015 life duration tables published for the Polish market (separately for each gender) by the Polish Statistical Central Office. It was also assumed that the increased demand for financial support by elderly persons is generated largely by the need to ensure a proper supply of medication and by other medical expenses (particularly expensive medical services and care offered by the private sector). Moreover, Szafranek (2016) aptly observed that personal hygiene is one of the most important elements of comfortable and respectable ageing. For this reason, expenses in this segment were considered the second most important determinant of the increased demand for financial support in the senior years. In addition to the above, the following assumptions were also made:

(1) The secondary market price for a square meter of residential property was calculated as the secondary market average square-meter price of residential property located in

\footnotetext{
${ }^{2}$ According to the report "Equity release market in sale model, years: 2010-2017" [in Polish] published by the Conference of Financial Companies in Poland, the cities of Warsaw and Wroclaw were the market leaders in terms of finalised sale model agreements.
} 
Warsaw or in Wroclaw (at 2015 prices), which was PLN 7401 (EUR 1805) for Warsaw and PLN 5177 (EUR 1262) for Wroclaw.

(2) Calculations assumed the average property space to be 50 square meters, corresponding to the equity release based on a total property value of PLN 370050 (EUR 90 256) for Warsaw or PLN 258850 (EUR 63 134) for Wroclaw.

(3) The discount rate represented the average interest rate for a mortgage loan granted in PLN in the year 2015, which was $4.5 \%$.

(4) The average Healthy Life Years index for women aged 65 and males aged 65 living in Poland was assumed to be 8 years ${ }^{3}$.

(5) The phases of the ageing process were defined in accordance with the specifications of Zizza, Ellison and Wernette (2009).

(6) The inflation rate represented averages for the period 2006-2015, which (according to the Polish Statistical Central Office) amounted to $2.02 \%$.

(7) The increment rate $r$ was established at 10\%, corresponding to an increase in health and personal hygiene expenses per person in an exclusively senior household (i.e., those who in 2015 were past the age threshold of $60^{4}$ (SCO, 2017).

(8) The payment growth rate $g$ was set at $20 \%$, corresponding to a double value of the increment rate $r$.

(9) The equity release agreements based on temporary annuities were assumed to be held for a period of 25 years.

In addition, all valuations were performed for three separate variants of the $\alpha$ value, namely: $0.3,0.4$ and 0.5 , corresponding to the base value of the agreement set at $30 \%, 40 \%$, or $50 \%$ of the current market value of the residential property.

\subsection{Results of valuations for a two-phase plan of payment}

Based on the above calculations, the findings were as follows:

- Values of monthly benefits paid to a beneficiary aged 65 for the next 25 years, to a value of $R$ over the initial 8 years and a value of $\tilde{R}$ for the remaining 17 years, with $\widetilde{R}=R \cdot 1.1$ (Tab. 1).

- Values of the first annual benefit paid for a period of 25 years, with annual value increase based on the current inflation rate for the first 8 years and the increment rate of $r$ over the next 17 years (Tab. 2).

- Values of monthly benefits paid in the value of $R$ for the initial 8 years, and in the value of $\tilde{R}=R \cdot 1.1$ over the remaining period (up to the beneficiary's demise) (Tab. 3).

\footnotetext{
${ }^{3}$ According to Eurostat data for residents of Poland, in 2015, the life expectancy at age 65 was 8.4 years for women and 7.6 years for men.

${ }^{4}$ Sadly, access to information on the financial standing of persons in their senior years is limited, as no data of this type was published in earlier periods.
} 
Table 1 . The monthly values of a 25 -year temporary life annuity benefit for a male aged 65 and a female aged 65 for a two-phase plan of payment

\begin{tabular}{|c|c|c|c|}
\hline City & $\begin{array}{l}\text { The monthly value of } \\
\text { temporary life annuity } \\
\text { benefit for } \alpha=0.5 \text { (in PLN) }\end{array}$ & $\begin{array}{l}\text { The monthly value of } \\
\text { temporary life annuity } \\
\text { benefit for } \alpha=0.4 \text { (in } \\
\text { PLN) }\end{array}$ & $\begin{array}{c}\text { The monthly value of } \\
\text { temporary life annuity } \\
\text { benefit for } \alpha=0.3 \text { (in PLN) }\end{array}$ \\
\hline \multicolumn{4}{|c|}{ Male aged 65} \\
\hline \multirow[t]{2}{*}{ Warsaw } & $R=1431.54$ & $R=1145.23$ & $R=858.92$ \\
\hline & $\tilde{R}=1574.69$ & $\tilde{R}=1259.75$ & $\widetilde{R}=944.81$ \\
\hline \multirow[t]{2}{*}{ Wroclaw } & $R=1001.36$ & $R=801.09$ & $R=600.81$ \\
\hline & $\tilde{R}=1101.49$ & $\tilde{R}=881.19$ & $\widetilde{R}=660.89$ \\
\hline \multicolumn{4}{|c|}{ Female aged 65} \\
\hline \multirow[t]{2}{*}{ Warsaw } & $R=1204.94$ & $R=963.95$ & $R=722.96$ \\
\hline & $\tilde{R}=1325.43$ & $\tilde{R}=1060.34$ & $\tilde{R}=795.26$ \\
\hline \multirow[t]{2}{*}{ Wroclaw } & $R=842.85$ & $R=674.28$ & $R=505.71$ \\
\hline & $\tilde{R}=927.14$ & $\tilde{R}=741.71$ & $\tilde{R}=556.28$ \\
\hline
\end{tabular}

Source: own study

Table 2. The first annual payment of a 25-year temporary life annuity for a male aged 65 and a female aged 65 in PLN for a two-phase plan of payment

\begin{tabular}{cccc}
\hline City & $\begin{array}{c}\text { The first annual payment of } \\
\text { a 25-year temporary life } \\
\text { annuity for } \alpha=0.5 \text { (in } \\
\text { PLN) }\end{array}$ & $\begin{array}{c}\text { The first annual payment of } \\
\text { a 25-year temporary life } \\
\text { annuity for } \alpha=0.4 \text { (in } \\
\text { PLN) }\end{array}$ & $\begin{array}{c}\text { The first annual payment } \\
\text { for a 25-year temporary life } \\
\text { annuity for } \alpha=0.3 \text { (in } \\
\text { PLN) }\end{array}$ \\
\hline Warsaw & 5864.72 & Female aged 65 & \\
\hline Wroclaw & 4102.37 & 4691.77 & 3518.83 \\
\hline \multicolumn{5}{c}{} & 3281.89 & 2461.42 \\
\hline Warsaw & 8301.66 & Male aged 65 & 4980.99 \\
\hline Wroclaw & 5807.01 & 6641.33 & 3484.20 \\
\hline
\end{tabular}

Source: own study

Table 3. The monthly values of a whole life annuity benefit for a male aged 65 and a female aged 65 for a two-phase plan of payment

\begin{tabular}{|c|c|c|c|}
\hline City & $\begin{array}{c}\text { The monthly value of a } \\
\text { whole life annuity benefit for } \\
\alpha=0.5 \text { (in PLN) }\end{array}$ & $\begin{array}{l}\text { The monthly value of a } \\
\text { whole life annuity benefit } \\
\text { for } \alpha=0.4 \text { (in PLN) }\end{array}$ & $\begin{array}{l}\text { The monthly value of a } \\
\text { whole life annuity benefit } \\
\text { for } \alpha=0.3 \text { (in PLN) }\end{array}$ \\
\hline \multicolumn{4}{|c|}{$\begin{array}{ll}\text { Female aged } 65 \\
\end{array}$} \\
\hline \multirow[t]{2}{*}{ Warsaw } & $R=1163.64$ & $R=930.91$ & $R=698.18$ \\
\hline & $\widetilde{R}=1280.00$ & $\tilde{R}=1024.00$ & $\tilde{R}=768.00$ \\
\hline \multirow[t]{2}{*}{ Wroclaw } & $R=813.97$ & $R=651.17$ & $R=488.38$ \\
\hline & $\widetilde{R}=895.36$ & $\tilde{R}=716.29$ & $\tilde{R}=537.22$ \\
\hline \multicolumn{4}{|c|}{ Male aged 65} \\
\hline \multirow[t]{2}{*}{ Warsaw } & $R=1402.79$ & $R=1123.03$ & $R=842.27$ \\
\hline & $\widetilde{R}=1544.17$ & $\widetilde{R}=1235.33$ & $\widetilde{R}=926.50$ \\
\hline \multirow[t]{2}{*}{ Wroclaw } & $R=981.95$ & $R=785.60$ & $R=589.17$ \\
\hline & $\tilde{R}=1080.14$ & $\tilde{R}=864.12$ & $\widetilde{R}=648.09$ \\
\hline
\end{tabular}

Source: own study 


\subsection{Results of valuations for a three-phase plan of payment}

Based on the above calculations the findings were as follows:

- Values of monthly benefits paid to a beneficiary aged 65 for the next 25 years, with payment value increasing by $10 \%$ past the age of 75 and $20 \%$ past the age of 85 (Tab. 4).

- Values of monthly benefits paid to a beneficiary aged 65 for their entire lifetime (whole life annuity), with payment value increasing by $10 \%$ past the age of 75 and $20 \%$ past the age of 85 (Tab. 5).

Table 4 . The monthly values of a 25 -year temporary life annuity benefit for a male aged 65 and a female aged 65 for a three-phase plan of payment

\begin{tabular}{|c|c|c|c|}
\hline City & $\begin{array}{c}\text { The monthly value of a } \\
\text { temporary life annuity } \\
\text { benefit for } \alpha=0.5 \text { (in PLN) }\end{array}$ & $\begin{array}{c}\text { The monthly value of a } \\
\text { temporary life annuity } \\
\text { benefit for } \alpha=0.4 \text { (in PLN) }\end{array}$ & $\begin{array}{l}\text { The monthly value of a } \\
\text { temporary life annuity } \\
\text { benefit for } \alpha=0.3 \text { (in PLN) }\end{array}$ \\
\hline \multicolumn{4}{|c|}{ Male aged 65} \\
\hline \multirow[t]{3}{*}{ Warsaw } & $R=1431.58$ & $R=1145.27$ & $R=858.95$ \\
\hline & $L=1574.74$ & $L=1259.79$ & $L=944.84$ \\
\hline & $P=1889.69$ & $P=1511.75$ & $P=1133.81$ \\
\hline \multirow[t]{3}{*}{ Wroclaw } & $R=1001.39$ & $R=801.11$ & $R=600.83$ \\
\hline & $L=1101.53$ & $L=881.22$ & $L=660.92$ \\
\hline & $P=1321.84$ & $P=1057.47$ & $P=793.10$ \\
\hline \multicolumn{4}{|c|}{ Female aged 65} \\
\hline \multirow[t]{3}{*}{ Warsaw } & $R=1199.56$ & $R=959.65$ & $R=719.74$ \\
\hline & $L=1319.52$ & $L=1055.61$ & $L=791.71$ \\
\hline & $P=1583.42$ & $P=1266.74$ & $P=950.05$ \\
\hline \multirow[t]{3}{*}{ Wroclaw } & $R=839,09$ & $R=671.27$ & $R=503.45$ \\
\hline & $L=923,01$ & $L=738.40$ & $L=553.80$ \\
\hline & $P=1107,61$ & $P=886.08$ & $P=664.56$ \\
\hline
\end{tabular}

Source: own study

Table 5. The monthly values of a whole life annuity benefit for a male aged 65 and a female aged 65 for a three-phase plan of payment

\begin{tabular}{|c|c|c|c|}
\hline City & $\begin{array}{l}\text { The monthly value of a } \\
\text { whole life annuity benefit } \\
\text { for } \alpha=0.5 \text { (in PLN) }\end{array}$ & $\begin{array}{c}\text { The monthly value of a } \\
\text { whole life annuity benefit for } \\
\alpha=0.4 \text { (in PLN) }\end{array}$ & $\begin{array}{l}\text { The monthly value of a } \\
\text { whole life annuity benefit } \\
\text { for } \alpha=0.3 \text { (in PLN) }\end{array}$ \\
\hline \multicolumn{4}{|c|}{ Male aged 65} \\
\hline \multirow[t]{3}{*}{ Warsaw } & $R=1398.41$ & $R=1118.72$ & $R=839.04$ \\
\hline & $L=1538.25$ & $L=1230.60$ & $L=922.95$ \\
\hline & $P=1845.90$ & $P=1476.72$ & $P=1107.54$ \\
\hline \multirow[t]{3}{*}{ Wroclaw } & $R=978.18$ & $R=782.55$ & $R=586.91$ \\
\hline & $L=1076.00$ & $L=860.8052$ & $L=645.60$ \\
\hline & $P=1291.20$ & $P=1032.966$ & $P=774.72$ \\
\hline \multicolumn{4}{|c|}{ Female aged 65} \\
\hline \multirow[t]{3}{*}{ Warsaw } & $R=1150.77$ & $R=920.61$ & $R=690.46$ \\
\hline & $L=1265.85$ & $L=1012.68$ & $L=759.51$ \\
\hline & $P=1519.02$ & $P=1215.21$ & $P=911.41$ \\
\hline \multirow[t]{3}{*}{ Wroclaw } & $R=804.96$ & $R=643.97$ & $R=482.97$ \\
\hline & $L=885.46$ & $L=708.37$ & $L=531.27$ \\
\hline & $P=1062.55$ & $P=850.04$ & $P=637.53$ \\
\hline
\end{tabular}

Source: own study 
The results of annuity valuations for all variants of payment clearly suggest that the values of benefits paid to female beneficiaries are decidedly lower than those paid to males. This trend is largely influenced by the more favourable average life expectancy for females at age 65. Gender differences in the value of benefits paid are most distinct for geometrically increasing $n$-year temporary life annuities paid at the beginning of each year - under this plan, males can expect their benefits to be as much as $41.5 \%$ in excess of that calculated for females. The least distinct gender differences were found between the values of benefits paid under temporary life annuities in a two-phase plan of payment - where the advantage for males was $18.5 \%$. For the remaining cases, the values of benefits paid to women were, on average, $21 \%$ lower than those paid to men in the same age profile.

To establish whether the above valuations may be perceived as attractive for elderly customers, it is useful to compare them against values offered by other sources of an elderly person's (or an elderly household's) income. Old-age pension benefits are the most fundamental source of disposable income for the elderly (and a sole source for many). The average value of an old-age pension benefit paid in 2015 amounted to PLN 1698 (EUR 414.15) for women and PLN 2481.18 (EUR 605.16) for men (CSO, 2016). Table 6 presents the results of the above valuations for all variants as a percentage of the average old-age pension benefit payoff and for different $\alpha$ base values. Importantly, elderly persons, when faced with decisions regarding the use of equity release products, will naturally tend to perceive their value in the context of other sources of disposable income as it may be difficult to predict agendas and plans for the valorisation of future old-age pension benefits.

Table 6. The value of a benefit paid from an equity release product expressed as a $\%$ of the average monthly old-age pension benefit paid in 2015 (by gender)

\begin{tabular}{|c|c|c|c|c|c|}
\hline \multirow[t]{2}{*}{ Variant } & \multicolumn{3}{|c|}{ Wroclaw } & \multicolumn{2}{|c|}{ Warsaw } \\
\hline & $\alpha$ & male & female & male & female \\
\hline \multirow{6}{*}{$\begin{array}{l}\text { 25-year temporary life annuity, a } \\
\text { two-phase plan of payment }\end{array}$} & \multirow[t]{2}{*}{0.5} & $40.36 \%$ & $49.64 \%$ & $57.70 \%$ & $70.96 \%$ \\
\hline & & $44.39 \%$ & $54.60 \%$ & $63.47 \%$ & $78.06 \%$ \\
\hline & \multirow[t]{2}{*}{0.4} & $32.29 \%$ & $39.71 \%$ & $46.16 \%$ & $56.77 \%$ \\
\hline & & $35.52 \%$ & $43.68 \%$ & $50.77 \%$ & $62.45 \%$ \\
\hline & \multirow[t]{2}{*}{0.3} & $24.22 \%$ & $29.78 \%$ & $34.62 \%$ & $42.58 \%$ \\
\hline & & $26.64 \%$ & $32.76 \%$ & $38.08 \%$ & $46.84 \%$ \\
\hline \multirow[t]{2}{*}{ whole life annuity, } & \multirow[t]{2}{*}{0.5} & $39.58 \%$ & $47.94 \%$ & $56.58 \%$ & $68.53 \%$ \\
\hline & & $43.53 \%$ & $52.73 \%$ & $62.24 \%$ & $75.38 \%$ \\
\hline \multirow[t]{4}{*}{ a two-phase plan of payment } & \multirow[t]{2}{*}{0.4} & $31.66 \%$ & $38.35 \%$ & $45.26 \%$ & $54.82 \%$ \\
\hline & & $34.83 \%$ & $42.18 \%$ & $49.79 \%$ & $60.31 \%$ \\
\hline & \multirow[t]{2}{*}{0.3} & $23.75 \%$ & $28.76 \%$ & $33.95 \%$ & $41.12 \%$ \\
\hline & & $26.12 \%$ & $31.64 \%$ & $37.34 \%$ & $45.23 \%$ \\
\hline \multirow{9}{*}{$\begin{array}{l}\text { 25-year temporary life annuity, a } \\
\text { three-phase plan of payment }\end{array}$} & \multirow[t]{3}{*}{0.5} & $40.36 \%$ & $49.42 \%$ & $57.70 \%$ & $70.65 \%$ \\
\hline & & $44.40 \%$ & $54.36 \%$ & $63.47 \%$ & $77.71 \%$ \\
\hline & & $53.27 \%$ & $65.23 \%$ & $76.16 \%$ & $93.25 \%$ \\
\hline & \multirow[t]{3}{*}{0.4} & $32.29 \%$ & $39.53 \%$ & $46.16 \%$ & $56.52 \%$ \\
\hline & & $35.52 \%$ & $43.49 \%$ & $50.77 \%$ & $62.17 \%$ \\
\hline & & $42.62 \%$ & $52.18 \%$ & $60.93 \%$ & $74.60 \%$ \\
\hline & \multirow[t]{3}{*}{0.3} & $24.22 \%$ & $29.65 \%$ & $34.62 \%$ & $42.39 \%$ \\
\hline & & $26.64 \%$ & $32.62 \%$ & $38.08 \%$ & $46.63 \%$ \\
\hline & & $31.96 \%$ & $39.14 \%$ & $45.70 \%$ & $55.95 \%$ \\
\hline \multirow[t]{3}{*}{ whole life annuity, } & \multirow[t]{3}{*}{0.5} & $39.42 \%$ & $47.41 \%$ & $56.36 \%$ & $67.77 \%$ \\
\hline & & $43.37 \%$ & $52.15 \%$ & $62.00 \%$ & $74.55 \%$ \\
\hline & & $52.04 \%$ & $62.58 \%$ & $74.40 \%$ & $89.46 \%$ \\
\hline
\end{tabular}


a three-phase plan of payment

\begin{tabular}{crrrr}
\multirow{3}{*}{0.4} & $31.54 \%$ & $37.93 \%$ & $45.09 \%$ & $54.22 \%$ \\
\cline { 2 - 5 } & $34.69 \%$ & $41.72 \%$ & $49.60 \%$ & $59.64 \%$ \\
\cline { 2 - 5 } 0.3 & $41.63 \%$ & $50.06 \%$ & $59.52 \%$ & $71.57 \%$ \\
\cline { 2 - 5 } $03.65 \%$ & $28.44 \%$ & $33.82 \%$ & $40.66 \%$ \\
\cline { 2 - 5 } & $26.02 \%$ & $31.29 \%$ & $37.20 \%$ & $44.73 \%$ \\
\hline & $31.22 \%$ & $37.55 \%$ & $44.64 \%$ & $53.68 \%$ \\
\hline
\end{tabular}

Source: own study

By relating the values of payoffs offered by equity release products to the value of average monthly old-age pension benefits paid to male and female beneficiaries, it is clear that the values are decidedly in favour of women. Thus, women are the clear winners in terms of the total sum of support received from an equity release product, even though the nominal values of received payments are lower than those for men. From the viewpoint of the beneficiary, the most favourable solution is the lifetime model (particularly the three-phase plan) as the last phase offers a relatively high benefit in terms of value (compared to the oldage pension benefit). Thus, recipients in their most senior years can rely on a sizeable support from the equity release to fund their growing needs. However, the probability of living past the final old age threshold is relatively low. In 2015, the average life expectancy of a person aged 65 was 20.1 years for women and 15.7 years for men (OECD, 2018). It should also be noted that, for male beneficiaries, the values of benefits paid under a two-phase plan of 25-year temporary life annuities are almost identical to those offered by the two initial phases of the three-phase variant of the same model. Furthermore, first-phase payoffs under a two-phase plan are paid for a period of 8 years, whereas the same phase in a three-phase plan covers a period of 10 years. This only adds to the subjectivity of decisions made in this context.

For some elderly persons, annual payments may be a very comfortable arrangement. In this model, beneficiaries receive sizeable annual instalments that can be utilised to cover additional expenses in the first or second phase of old-age (holidays, home improvements, etc.). After passing the second age threshold, they may utilise the increased volume of support to purchase expensive life-improvement products and medical services.

It is also notable that, compared to other markets and global providers, Polish institutions offering equity release products may be reluctant to agree upon $\alpha=0.5$ as the basis for their annuity calculations. Analysing the above calculations for the remaining $\alpha$ base values shows that, for females with residential properties in Wroclaw, the initial values of monthly benefits in both variants (two-phase and three-phase) are within the $40 \%$ value of the old-age pension benefit for $\alpha=0.4$ and the $30 \%$ value threshold for $\alpha=0.3$; for males, the corresponding values are $33 \%$ and $25 \%$, respectively. For female holders of property located in Warsaw, the initial values of monthly benefits in both variants (two-phase and three-phase) are within the $57 \%$ value of the old-age pension benefit for $\alpha=0.4$ and the $43 \%$ value threshold for $\alpha=0.3$; for males, the corresponding values are $47 \%$ and $35 \%$, respectively.

\section{Conclusion}

As shown in the brief summary of demographic trends and changes, senior citizens will be increasingly inclined to seek sources of additional income. Equity release products may be an attractive solution in this regard, particularly for those who, for various reasons, lack sufficient savings from earlier years of gainful employment. In addition, with the passing of each consecutive phase of the ageing process, elderly people require increased financial support to cover the cost of medication, private health care, and/or nursing services. Moreover, recent EU trends with regard to formal retirement age thresholds will make it difficult for children to take 
sufficient care of elderly parents in advanced stages of ageing. It can therefore be assumed that senior citizens will require increased financial support from private sector institutions.

The payment plans proposed in this article, adjusted to the growing needs and financial requirements of senior-only households, seem to offer a good solution. The wealth of findings presented herein, based on valuations of benefits paid in two-phase and three-phase models of payment, may stimulate public interest in equity release products. Additionally, they may also increase public awareness of the need to take proper care and maintenance of privately owned residential property, as this may be of fundamental significance to the provider of such services, be this a bank, an insurance company, or a mortgage fund.

Finally, the use of term benefits involves the exhaustion of capital after a certain number of years. This situation can be particularly difficult for people who will be at a very advanced age and whose financial needs will be even greater. Therefore, some elderly people may be more interested in life annuity payments.

\section{Acknowledgment}

The project is financed by the Ministry of Science and Higher Education in Poland under the program "Regional Initiative of Excellence" 2019 - 2022 project number 015/RID/2018/19 total funding amount 10721 040,00 PLN.

\section{References}

Alai, D.H., Chen, H., Cho, D., Hanewald, K., \& Sherris M. (2014). Developing equity release markets: risk analysis for reverse mortgages and home reversionsю North American Actuarial Journal, 18(1), 217-241.

Barrieu, P., Bensusan H., Karoui N.E., Hillairet C., Loisel S., Ravanelli C. \& Salhi Y. (2012). Understanding, modelling and managing longevity risk: key issues and main challenges. Scandinavian Actuarial Journal, 3, 203-231.

Bisetti, E., \& Favero C.A. (2014). Measuring the impact of longevity risk on pension systems: the case of Italy. North American Actuarial Journal, 18(1), 87-103. doi:10.1080/10920277.2013.852463.

Bhuyan, V.B. (2011). Reverse mortgages and linked securities, New Jersey: John Wiley\&Sons.

Bloom, D.E., Chatterji S., Kowal, P., Lloyd-Sherlock, McKee M., Rechel B., Rosenberg L., \& Smith J.P. (2015). Macroeconomic implications of population ageing and selected policy responses. The Lancet, 385, 649-657.

Bowers, N.L. (1997). Actuarial Mathematics, Schaumburg: The Society of Actuaries.

Central Statistical Office (2017). Sytuacja materialna i dochodowa gospodarstw domowych emerytów i rencistów oraz gospodarstw domowych majacych $w$ swoim składzie osoby starsze w wieku 60 lat lub więcej w 2016 r. Warsaw: Central Statistical Office.

Chen, Y., \& Wu Q. (2014). Research on risk of implementing housing reverse mortgages in China. International Journal of Business and Social Science, 5(9), 78-80.

Choi H-S.(2019). A Numerical analysis to study whether the early termination of reverse mortgages is rational. Sustainability, 11, 1-10. doi:10.3390/su11236820.

Clark, R., d'Ambrosio M., McDermed A.A. \& Sawant K. (2003). Financial education and retirement savings. Paper presented at Sustainable Community Development: What Works, What Doesn't, and Why Conference Sponsored by the Federal Reserve System, Washington, March 27-28.

Davidoff, T., \& Welke G. (2004). Selection and Moral Hazard in the Reverse Mortgage Market, SSRN Electronic Journal. doi: 10.2139/ssrn.608666. 
Dickson, D.C.M., Hardy M.R., \& Waters H.R. (2013). Actuarial Mathematics for Life Contingent Risk, New York: Cambridge University Press.

Eichhorst, W., M. Gerard, M.J. Kendzia, C. Mayrhuber, C. Nielsen, G. Runstler, \& Url, T. (2011). Pension systems in the EU - contingent liabilities and assets in the public and private sector. Retrieved February 8, 2018, from http://www.europarl.europa.eu

Equity Release Council. (2016). Accessing your property wealth through Equity Release. Retrieved January 12, 2018, from http://www.equityreleasecouncil.com

European Commission, Healthy Life Years at age 65, Retrieved January 10, 2018, from http://ec.europa.eu/health

Fong, J.H., Mitchell O.S., \& Koh B.S.K. (2011). Longevity risk management in Singapore's national pension system. The Journal of Risk and Insurance, 78(4), 961-981. doi:10.1111/j.1539-6975.2010.01401.x.

Fornero, E., Rossi M. \& Urzi Brancati M.C. (2016). Explaining why, right or wrong, (Italian) households do not like reverse mortgages. Journal of Pension Economics and Finance, $15(2), 180-202$.

Guerin, J. (2012). The history of the HECM: A detailed timeline. The Reverse Review, October, 40-45.

Gupta, A.K. (2016). Reverse mortgage - silver lining for golden years. Imperial Journal of Interdisciplinary Research, 2(5), 609-614.

Heo, Y.C., An S., \& Hong. B.E. (2016). Reverse mortgage as an income stabilizer for the elderly in Korea. Asian Social Work and Policy Review, 10, 103-112.

Huang, H.C., Wang C.W., \& Miao Y.C. (2011). Securitisation of Crossover Risk in reverse mortgages. The Geneva Papers on risk and Insurance: Issues and Practice, 36(4), 622647. doi:10.1057/gpp.2011.23.

International Monetary Fund. (2012). The financial impact of longevity risk. Chapter 4 in IMF Global Financial Stability Report, 1-31.

Johnson, D.W., \& Simkins Z.S. (2014). Retirement trends, current monetary policy, and the reverse mortgage market. Journal of Financial Planning, 27(3), 52-59.

Kobayashi, M., Konishi S., \& Takeishi T. (2017). The Reverse Mortgage Market in Japan and Its Challenges. A Journal of Policy Development and Research, 19(1), 99-118.

Kowalczyk-Rólczyńska, P. (2016). Managing the demographic risk of pension systems. Review of Business and Economics Studies, 4(4), 23-31.

Kowalczyk-Rólczyńska, P. (2015). Rola odwróconego kredytu hipotecznego w zabezpieczeniu emerytalnym [The role of a reverse mortgage in pension security]. Praca i Zabezpieczenie Społeczne, 8, 111-122.

Lannoo, K., M. Barslund, A. Chmelar, \& M. Werder. 2014. Pension Schemes. Retrieved January 15, 2018 from http://www.europarl.europa.eu/RegData/etudes/STUD/2014/536281/IPOL_STU(2014)53 6281_EN.pdf

Lee, Y.T., Wang C.W., \& Huang H.C. (2012). On the valuation of reverse mortgages with regular tenure payments. Insurance: Mathematics and Economics, 51, 430-441. doi:10.1016/j.insmatheco.2012.06.008.

Lee, Y.T., Kung K-L., Liu I-Ch (2018). Profitability and risk profile of reverse mortgages: A cross-system and cross-plan comparison. Insurance: Mathematics and Economics, 78, 255-266. doi:10.1016/j.insmatheco.2017.09.019

Li, J.S.H., Hardy M.R., \& Tan K.S. (2010). On pricing and hedging the no-negative-equity guarantee in equity release mechanism. The Journal of Risk and Insurance, 77(2), 499522.

Lusardi, A. (2009). Planning for retirement: the importance of financial literacy. Public Policy \& Aging Report, 19(3), 7-13. doi:10.1093/ppar/19.3.7. 
Mazonans, P.M. (2011). The History of reverse mortgages: an insider's view. In V.B. Bhuyan (Eds.), Reverse mortgages and linked securities, 8-16. New Jersey: John Wiley\&Sons.

Melis, R., \& Trudda A. (2010). Demographic risk indicators in pay-as you-go pension funds. Problems and Perspectives in Management, 8(4), 117-126.

Marciniuk, A. (2014). Renta hipoteczna a odwrócony kredyt hipoteczny na rynku polskim. [Reverse Annuity Contract and Reverse Mortgage on the Polish Market.]. Slaski Przeglad Statystyczny, 12(18), 253-272. doi:10.15611/sps.2014.12.14.

Nakajima, M., \& Telyukova I.A. (2013). Reverse Mortgage Loans: A quantitative analysis. Working Papers 13-27. Research Department, Federal Reserve Bank Of Philadelphia

Nakajima, M., \& Telyukova I.A. (2017). Reverse Mortgage Loans: A Quantitative Analysis. The Journal of Finance, 72(2), 911-950. doi:10.1111/jofi.12489.

National Bank of Poland. (2017). Zasobność gospodarstw domowych $w$ Polsce [The households' wealth in Poland] Warsaw

Ntalianis, M., \& Wise V. (2011). The role of financial education in retirement planning. Australasian Accounting, Business and Finance Journal, 5(2), 23-37.

OECD. (2017). Pensions at a Glance 2017. OECD and G20 Indicators.

OECD. (2011). Pensions at a Glance 2011. Retirement-income System in OECD and G20 Countries.

Reed, R., \& Gibler, K.M. (2003). The case for reverse mortgages in Australia: applying the USA experience. Proceedings of the 9th Annual Conference of the Pacific Rim Real Estate Society 2003, 1-13. Brisbane: Pacific Rim Real Estate Society.

Reifner, U., Clerc-Renaud, S., Pérez-Carrillo E.F., Tiffe A. \& Knobloch M. (2009). Study on Equity Release Schemes in the EU, Part I: General Report. Retrieved January 10, 2018.

Szafranek, A. (2016). "Czym jest pomyślne starzenie się?” [What is successful aging?]. In M. Cybulski \& E. Krajewska-Kułak (Eds.) Edukacja prozdrowotna seniorów jako szansa na pomyślne starzenie się na przyktadzie miasta Białegostoku, 11-22. Białystok: Duchno.

Terry, R., \& Gibson, R. (2006). Obstacles to equity release. York: Joseph Rowntree Foundation.

Whiteford, P., \& Whitehouse, E. (2006). Pension challenges and pension reforms in OECD countries. Oxford Review of Economic Policy, 22(1), 78-94.

Towers Watson. (2013). Equity release. Accessing housing wealth in retirement. Retrieved January 20, 2018 from https://www.towerswatson.com/en/Insights/IC-Types/Ad-hocPoint-of-View/2013/06/Equity-release-Accessing-housing-wealth-in-retirement

Tunaru, R.S.,(2017). Real-Estate derivatives: From Econometrics to Financial Engineering. New York: Oxford University Press.

Yang, S.S. (2011). Securitization and tranching longevity and house price risk for reverse mortgage products. The Geneva Paper on risk and Insurance - Issues and Practice, Special Issue on Longevity, 36(4), 648-674. doi: 10.1057/gpp.2011.26.

Wang, P. \& KimJ.P. (2014). The value of reverse mortgage loans: case study of the Chinese market. Journal of Asian Finance, Economics and Business, 1(4), 5-13. doi:10.13106/jafeb.2014.vol1.no4.5.

World Health Organization. (2004). A glossary of terms for community health care and services for older persons Retrieved January 24, 2018 from http://www.who.int/kobe_centre/ageing/ahp_vol5_glossary.pdf

Wang L., Valdez E.A., \& Piggott J. (2008). Securitization of longevity risk in reverse mortgages. North American Actuarial Journal, 12(4), 345-371. doi: $10.1080 / 10920277.2008 .10597529$.

Zizza, C.A., Ellison K.J.,\& Wernette C.M. (2009). Total water intakes of community-living middle-old and oldest-old adults. Journal of Gerontology Series A:Biological Sciences and Medical Sciences, 64A(4), 481-486. doi: 10.1093/gerona/gln045. 